\title{
Kajian Interaksi Obat Antihipertensi Pada Pasien Rawat Inap di Salah Satu Rumah Sakit di Bogor, Indonesia
}

Lusi Indriani, Emy Oktaviani*

Bagian Farmasi Klinis, Prodi Farmasi, Fakultas MIPA, Universitas Pakuan Bogor

*Email korespondensi: emy.oktaviany@unpak.ac.id

(Submit 15/03/2019, Revisi 05/09/2019, Diterima 20/12/2019)

\begin{abstract}
Abstrak
Dewasa ini, penyakit hipertensi menjadi salah satu penyakit degeneratif yang umum terjadi pada kalangan masyarakat di dunia khususnya Indonesia. Pengobatan hipertensi dalam jangka waktu lama seringkali menimbulkan masalah baru pada penderita seperti munculnya komplikasi baik yang berasal dari obat maupun penyakit. Tingginya resiko komplikasi menyebabkan meningkatnya jumlah obat dan menyebabkan meningkatnya resiko interaksi obat. Penelitian ini bertujuan untuk mengetahui potensi kejadian interaksi obat antihipertensi berdasarkan tingkat signifikansi, tingkat keparahan dan mekanisme terbanyak serta mengidentifikasi obat antihipertensi yang paling sering berinteraksi. Desain penelitian observasional non eksperimental pendekatan retrospektif digunakan dalam penelitian ini. Rekam medis pasien sebanyak 74 pasien dilakukan kajian interaksi obat secara teoritik dengan penapisan secara manual menggunakan buku teks Drug Interactions Facts oleh David S. Tatro (2009) dan penapisan secara online menggunakan Medscape dan Drugs.com. Analisis data dengan menghitung persentase interaksi obat berdasarkan tingkat signifikansi, mekanisme, dan tingkat keparahan. Potensi kejadian interaksi obat terjadi pada 49 pasien $(66,2 \%)$ dengan jumlah 169 kasus interaksi. Berdasarkan mekanisme terdapat 108 kasus $(63,9 \%)$ interaksi farmakodinamik dan 25 kasus $(14,8 \%)$ interaksi farmakokinetik dan tidak diketahui sebanyak 36 kasus (21,3\%). Berdasarkan tingkat keparahan terdapat interaksi mayor 15 kasus (8,9\%), interaksi moderate 140 kasus $(82,8 \%)$ dan interaksi minor 14 kasus $(8,3 \%)$. Berdasarkan level signifikansi, kasus terbanyak terjadi pada level signifikansi 3 yaitu sebanyak 8 kasus $(4,7 \%)$ dan furosemid adalah obat antihipertensi yang paling banyak berinteraksi. Potensi kejadian interaksi obat pada pemakaian obat antihipertensi masih dikategorikan cukup tinggi (lebih dari $50 \%$ ). Tingginya potensi kejadian interaksi obat selama pengobatan dapat berpengaruh pada ketercapaian efek terapi dan meningkatkan resiko efek samping. Dengan demikian kolaborasi tenaga kesehatan khususnya farmasi diperlukan dalam upaya pemberian pengobatan yang aman dan efektif untuk menghindari terjadinya resiko interaksi obat. Perlu juga adanya monitoring pada pengobatan agar dapat mencegah terjadinya interaksi obat dan penanganan dini jika terjadinya interaksi obat aktual yang membahayakan secara klinis.
\end{abstract}

Kata kunci: Potensi interaksi obat, studi literatur, antihipertensi 


\section{Outline}

- Pendahuluan

- Metode

- Hasil dan Pembahasan

- Kesimpulan

- Ucapan Terima Kasih

- Daftar Pustaka

\section{Pendahuluan}

Hipertensi menjadi salah satu penyakit degeneratif yang umum terjadi pada kalangan masyarakat di dunia khususnya Indonesia. Hipertensi merupakan faktor risiko utama terjadinya stroke, infark miokard, penyakit pembuluh darah, penyakit ginjal kronik dan bahkan menyebabkan kematian jika tidak dideteksi dengan cepat dan tidak diobati dengan tepat 5 . American Heart Association (2014) melaporkan 69\% dari penderita serangan jantung, $77 \%$ dari penderita stroke dan $74 \%$ dari penderita gagal jantung mengidap hipertensi. Hipertensi juga terjadi pada $60 \%$ pasien diabetes melitus ${ }^{11}$.

Menurut survei Riset Kesehatan Dasar (Riskesdas) tahun 2013, prevalensi hipertensi di Indonesia telah mencapai $25,8 \%$ dari total penduduk dewasa dan prevalensi tertinggi ditemukan di Provinsi Kalimantan Selatan 39,6\%, dan terendah di Papua Barat 20,1\%.

Lebih dari dua pertiga pasien hipertensi tidak bisa dikontrol dengan satu obat dan akan menerima dua atau lebih obat antihipertensi dari kelas obat yang berbeda. Pasien hipertensi yang mendapatkan terapi kombinasi dan pasien hipertensi dengan penyakit penyerta berpotensi mengalami interaksi obat yang dapat mengakibatkan ketidaktercapaian efek terapi ${ }^{6}$.

Penelitian Yasin et al., (2005) menunjukkan bahwa interaksi obat potensial terjadi pada $90 \%$ pasien rawat inap dan $99,26 \%$ pasien rawat jalan. Pada pasien rawat inap ditemukan interaksi farmakokinetik sebanyak 20 jenis (50\%), interaksi farmakodinamik sebanyak 6 jenis (15\%). Jenis interaksi yang memiliki insidensi kejadian paling tinggi secara berurutan adalah furosemide dengan ACE Inhibitor yang terjadi pada 84 pasien $(76,36 \%)$, furosemide dengan asetosal pada 66 pasien $(60 \%)$, dan ACE Inhibitor dengan asetosal pada 57 pasien $(51,82 \%)$. Penelitian lain yang dilakukan oleh Mylapuram Rama et al., (2012) di salah satu rumah sakit di India, diketahui terjadi 474 interaksi obat pada 156 pasien ginjal kronis dengan $50,63 \%$ interaksi obat farmakodinamik dan $46,84 \%$ interaksi obat farmakokinetik.

Banyaknya kejadian interaksi obat tersebut mendorong peneliti untuk melakukan kajian interaksi obat antihipertensi pada salah satu rumah sakit di Bogor yang diharapkan dapat meminimalkan masalah yang mungkin timbul selama terapi.

\section{Metode}

Penelitian ini menggunakan data rekam medis pasien rawat inap, lembar pengumpul data, buku teks Drug Interactions Facts oleh David S. Tatro (2009), aplikasi Medscape dan Drugs.com. 


\section{A. Rancangan Penelitian}

Penelitian ini merupakan penelitian observasional Non-Eksperimental yang bersifat deskriptif dengan pendekatan retrospektif.

\section{B. Jalannya Penelitian}

Penelitian ini dilakukan melalui beberapa tahapan, yaitu studi pustaka mengenai penelitian, pengurusan ethical clearance penelitian, pengambilan data rekam medis pasien rawat inap pada lembar pengumpulan data, dan analisis data.

\section{Evaluasi Data}

Evaluasi kejadian interaksi obat antihipertensi dilakukan melalui studi perbandingan data pengobatan pada rekam medis dengan pustaka dan studi online menggunakan aplikasi Medscape dan Drugs.com. Data kemudian dianalisis secara kuantitatif dengan menghitung persentase potensi interaksi obat berdasarkan tingkat signifikansi, mekanisme, dan tingkat keparahan.

\section{Hasil dan Pembahasan}

\section{A. Hasil}

Karakteristik pasien berdasarkan jenis kelamin dapat dilihat pada Tabel 1, bahwa terdapat 29 pasien $(39,2 \%)$ laki-laki dan 45 pasien $(60,8 \%)$ perempuan dari 74 pasien yang menerima terapi obat antihipertensi.

Tabel 1. Karakteristik Pasien Berdasarkan Jenis Kelamin dan Usia

\begin{tabular}{|c|c|c|c|c|}
\hline No. & \multicolumn{2}{|c|}{ Karakteristik Pasien } & Jumlah Pasien & Persentase (\%) \\
\hline \multirow[t]{3}{*}{1.} & \multirow[t]{2}{*}{ Jenis Kelamin } & Laki-laki & 29 & 39,2 \\
\hline & & Perempuan & 45 & 60,8 \\
\hline & & Total & 74 & 100 \\
\hline \multirow[t]{3}{*}{2.} & \multirow[t]{3}{*}{ Usia } & $40-59$ & 48 & 64,9 \\
\hline & & $60-75$ & 26 & 35,1 \\
\hline & & Total & 74 & 100 \\
\hline
\end{tabular}

Karakteristik berdasarkan usia dikelompokkan menjadi 2 kelompok yaitu 40-59 tahun dan 60-75 tahun. Berdasarkan data rekam medis diketahui bahwa kelompok usia yang mendapatkan terapi obat antihipertensi paling banyak adalah kelompok usia 40-59 yaitu sebanyak 48 pasien $(64,9 \%)$.

Dari Tabel 2, penggunaan obat antihipertensi pada pasien rawat inap yang dianalisis terbagi menjadi 4 kelompok yaitu penggunaan obat tunggal sebanyak 31 pasien $(41,9 \%)$, kombinasi 2 obat sebanyak 19 pasien $(25,7 \%)$, kombinasi 3 obat sebanyak 19 pasien $(25,7 \%)$, dan kombinasi 4 obat sebanyak 5 pasien $(6,7 \%)$.

Dari Tabel 3, menunjukan bahwa angka kejadian interaksi obat pada 74 pasien didapatkan 25 pasien $(33,8 \%)$ tidak mengalami interaksi dan 49 pasien $(66,2 \%)$ mengalami interaksi obat. Sedangkan untuk persentase kejadian interaksi obat antihipertensi berdasarkan tingkat signifikansi dan distribusi jenis interaksi obat antihipertensi yang terjadi terlihat bahwa terdapat 1 kasus dengan tingkat signifikansi 1 dengan jenis obat Furosemid dan Digoxin, terdapat 1 kasus dengan tingkat signfikansi 2 dengan jenis obat bisoprolol dan digoxin, terdapat 8 kasus dengan tingkat signifikansi 
3 dengan jenis obat furosemid dan captopril (sebanyak 5 kasus) dan furosemid dan ramipril (sebanyak 3 kasus), terdapat 2 kasus dengan tingkat signifikansi 4 dengan jenis obat ramipril dan spironolakton, 1 kasus dengan tingkat signifikansi 5 dengan jenis obat furosemid dan parasetamol dan terdapat 156 kasus yang tidak diketahui tingkat signifikansinya. Hasil dapat dilihat pada Tabel 4 dan 5.

Tabel 2. Pola Pengobatan Obat Antihipertensi Pada Pasien Rawat Inap

\begin{tabular}{|c|c|c|c|c|c|}
\hline No. & $\begin{array}{c}\text { Penggunaan } \\
\text { Obat }\end{array}$ & Nama Obat & $\begin{array}{l}\text { Jumlah } \\
\text { Pasien }\end{array}$ & Total & $(\%)$ \\
\hline \multirow{5}{*}{1.} & \multirow{5}{*}{ Obat Tunggal } & Valsartan & 1 & \multirow{5}{*}{31} & \multirow{5}{*}{41,9} \\
\hline & & Amlodipine & 25 & & \\
\hline & & Telmisartan & 2 & & \\
\hline & & Captopril & 2 & & \\
\hline & & Bisoprolol & 1 & & \\
\hline \multirow{11}{*}{2.} & \multirow{11}{*}{$\begin{array}{c}\text { Kombinasi } 2 \\
\text { Obat }\end{array}$} & Telmisartan+Furosemid & 2 & \multirow{11}{*}{19} & \multirow{11}{*}{25,7} \\
\hline & & Captopril+Bisoprolol & 2 & & \\
\hline & & Amlodipin+Telmisartan & 1 & & \\
\hline & & Ramipril+Furosemid & 1 & & \\
\hline & & Candesartan+Amlodipin & 2 & & \\
\hline & & Amlodipin+Bisoprolol & 2 & & \\
\hline & & Amlodipin+Furosemid & 2 & & \\
\hline & & Amlodipin+Valsartan & 3 & & \\
\hline & & Captopril+Furosemid & 2 & & \\
\hline & & Valsartan+Furosemid & 1 & & \\
\hline & & Telmisartan+Bisoprolol & 1 & & \\
\hline \multirow{14}{*}{3.} & \multirow{14}{*}{$\begin{array}{c}\text { Kombinasi } 3 \\
\text { Obat }\end{array}$} & Telmisartan+Furosemid+Bisoprolol & 1 & \multirow{14}{*}{19} & \multirow{14}{*}{25,7} \\
\hline & & Amlodipin+Bisoprolol+Telmisartan & 3 & & \\
\hline & & Amlodipin+Telmisartan+HCT & 1 & & \\
\hline & & Amlodipin+Furosemid+Valsartan & 2 & & \\
\hline & & Amlodipin+Valsartan+Captopril & 1 & & \\
\hline & & Amlodipin+Furosemid+Candesartan & 2 & & \\
\hline & & Amlodipin+Bisoprolol+Valsartan & 2 & & \\
\hline & & Amlodipin+Furosemid+Spironolakton & 1 & & \\
\hline & & Amlodipin+Propanolol+Valsartan & 1 & & \\
\hline & & Amlodipin+Telmisartan+Furosemid & 1 & & \\
\hline & & Captopril+Furosemid+Candesartan & 1 & & \\
\hline & & Candesartan+Furosemid+Bisoprolol & 1 & & \\
\hline & & Furosemid+Ramipril+Spironolakton & 1 & & \\
\hline & & Captopril+Bisoprolol+Furosemid & 1 & & \\
\hline \multirow{4}{*}{4.} & \multirow{4}{*}{$\begin{array}{c}\text { Kombinasi } 4 \\
\text { Obat }\end{array}$} & Amlodipin+Valsartan+Bisoprolol +Furosemid & 2 & \multirow{4}{*}{5} & \multirow{4}{*}{6,7} \\
\hline & & Amlodipin +Telmisartan+Bisoprolol +Furosemid & 1 & & \\
\hline & & Amlodipin+Captopril+Bisoprolol +Valsartan & 1 & & \\
\hline & & Ramipril+Amlodipin+Spironolakton $+\mathrm{HCT}$ & 1 & & \\
\hline
\end{tabular}


Tabel 3. Angka Kejadian Interaksi Obat Antihipertensi

\begin{tabular}{|c|c|c|c|}
\hline No. & Interaksi & Jumlah Pasien & Persentase (\%) \\
\hline 1. & Tidak terjadi interaksi & 25 & 33,8 \\
\hline 2. & Terjadi interaksi & 49 & 66,2 \\
\hline & Total & 74 & 100 \\
\hline
\end{tabular}

Tabel 4. Persentase Interaksi Obat Antihipertensi Berdasarkan Tingkat Signifikansi

\begin{tabular}{|c|c|c|c|}
\hline No. & Signifikansi & Jumlah Kasus & Persentase (\%) \\
\hline 1. & Signifikansi 1 & 1 & 0,6 \\
\hline 2. & Signifikansi 2 & 1 & 0,6 \\
\hline 3. & Signifikansi 3 & 8 & 4,7 \\
\hline 4. & Signifikansi 4 & 2 & 1,2 \\
\hline $\mathbf{5 .}$ & Signifikansi 5 & 1 & 0,6 \\
\hline 6. & Unknown & 156 & 92,3 \\
\hline & Total & 169 & 100 \\
\hline
\end{tabular}

Tabel 5. Distribusi Interaksi Obat Antihipertensi Berdasarkan Tingkat Signifikansi

\begin{tabular}{|c|c|c|c|}
\hline Signifikansi & Obat A & Obat B & $\begin{array}{c}\text { Jumlah Kasus } \\
(\mathbf{N}=169)\end{array}$ \\
\hline $\mathbf{1}$ & Furosemide & Digoxin & 1 \\
\hline $\mathbf{2}$ & Bisoprolol & Digoxin & 1 \\
\hline 3 & Furosemide & Captopril & 5 \\
\hline 4 & Furosemide & Ramipril & 3 \\
\hline $\mathbf{5}$ & Ramipril & Spironolakton & 2 \\
\hline
\end{tabular}

Analisis berikutnya adalah persentase kejadian interaksi obat berdasarkan tingkat keparahan terlihat bahwa dari 169 kasus terdapat 15 kasus (8,9\%) mayor, 140 kasus $(82,8 \%)$ moderate, dan 14 kasus $(8,3 \%)$ minor. Sedangkan persentase kejadian interaksi obat berdasarkan mekanismenya terlihat bahwa interaksi obat secara farmakodinamik 108 kasus (63,9\%) dan secara farmakokinetik 25 kasus (14,8\%), sebanyak 36 kasus $(21,35 \%)$ yang mekanismenya tidak diketahui. Hasil ini dapat dilihat pada Tabel 6 dan 7 .

Tabel 6. Persentase Interaksi Obat Antihipertensi Berdasarkan Tingkat Keparahan

\begin{tabular}{|c|c|c|c|}
\hline No. & Severity & Jumlah Kasus & Persentase (\%) \\
\hline 1. & Mayor & 15 & 8,9 \\
\hline 2. & Moderate & 140 & 82,8 \\
\hline 3. & Minor & 14 & 8,3 \\
\hline & Total & 169 & 100 \\
\hline
\end{tabular}

Tabel 7. Persentase Interaksi Obat Antihipertensi Berdasarkan Mekanisme

\begin{tabular}{|c|c|c|c|}
\hline No. & Mekanisme & Jumlah Kasus & Persentase (\%) \\
\hline 1. & Farmakodinamik & 108 & 63,9 \\
\hline 2. & Farmakokinetik & 25 & 14,8 \\
\hline 3. & Unknown & 36 & 21,3 \\
\hline & Total & 169 & 100 \\
\hline
\end{tabular}




\section{B. Pembahasan}

Hasil penelitian menunjukkan bahwa perempuan paling banyak menderita dan mendapatkan obat antihipertensi. Hal ini sesuai dengan penelitian yang dilakukan oleh Yosida (2016) di RSUD Panembahan Senopati Bantul bahwa kejadian hipertensi lebih banyak ditemukan pada perempuan $(58,3 \%)$ daripada laki-laki $(41,7 \%)$. Hal ini terjadi karena pengaruh dari hormone estrogen. Perempuan pasca menopause memiliki jumlah estrogen yang lebih sedikit sehingga efek penurunan LDL di hati oleh estrogen menurun, hal ini menyebabkan terjadinya penebalan pada dinding arteri yang merupakan faktor resiko hipertensi. Selain itu, berkurangnya produksi estrogen menyebabkan tubuh tidak dapat mempertahankan vasodilatasi yang dapat mengontrol tekanan darah ${ }^{2}$.

Usia 40-59 tahun pada penelitian ini paling banyak menderita dan mendapatkan obat antihipertensi $(64,9 \%)$. Penyakit hipertensi beresiko terjadi ketika mencapai usia paruh baya yaitu 40 tahun dan $\geq 60$ tahun. Prevalensi hipertensi dikalangan usia lanjut cukup tinggi yaitu sebesar $40 \%{ }^{9}$. Hal ini disebabkan oleh perubahan struktur pada pembuluh darah besar, sehingga lumen menjadi sempit dan dinding pembuluh darah menjadi kaku. Sehingga menyebabkan beban jantung untuk memompa darah bertambah berat sehingga terjadi peningkatan tekanan darah dalam sistem sirkulasi.

Dari data penggunaan obat antihipertensi menunjukkan bahwa kejadian interaksi obat lebih banyak $(66,2 \%)$ dibanding tidak adanya interaksi obat. Interaksi obat terjadi baik antar obat antihipertensi maupun dengan obat lain. Interaksi obat juga dianalisis berdasarkan tingkat signifikansi.

Berdasarkan Tatro (2009), signifikansi 1 berarti keparahan mayor yang dapat menimbulkan resiko yang berpotensi mengancam jiwa pasien serta mengakibatkan kerusakan yang permanen. Sehingga kombinasi kedua obat tersebut harus dihindari. Contoh kasusnya adalah furosemide dengan digoxin, dimana furosemide meningkatkan efek dari digoxin. Glikosida jantung menghambat natrium-kalium ATP-ase, yang berkaitan dengan transportasi ion natrium dan kalium melintasi membran sel miokard, sehingga meningkatkan aktivitas dan toksisitas dari digitalis. Adanya peningkatan ekskresi kalium dan magnesium dapat mempengaruhi otot jantung ${ }^{3}$.

Kategori signifikansi 2 memiliki keparahan moderat yang menimbulkan efek dapat mengakibatkan terjadinya penurunan status klinik pasien sehingga dibutuhkan terapi tambahan atau perawatan di rumah sakit. Contoh kasusnya adalah bisoprolol dengan digoxin dimana bisoprolol akan meningkatkan konsentrasi digoxin dan resiko terjadinya bradikardia (penurunan denyut jantung).

Kategori signifikansi klinis 3 memiliki keparahan minor yang dapat menimbulkan efek interaksi obat ringan dan secara signifikan tidak dapat mempengaruhi status klinik pasien sehingga terapi tambahan tidak diperlukan. Contoh kasusnya adalah furosemide dengan captopril. Interaksi antara captopril dengan furosemide akan meningkatkan efek antihipertensi sehingga dapat terjadi hipotensi akut dan dapat mengakibatkan penurunan fungsi. Monitoring tekanan darah dan fungsi ginjal perlu dilakukan.

Kategori signifikansi klinis 4 memiliki keparahan mayor atau moderat sehingga menimbulkan efek yang dapat berbahaya karena dapat mengubah respon farmakologi 
individu sehingga diperlukan terapi tambahan. Contoh kasusnya adalah ramipril dengan spironolakton dimana kemungkinan adanya peningkatan serum kalium pada pasien tertentu yang memiliki resiko tinggi. Monitoring fungsi ginjal dan kadar kalium perlu dilakukan. Kategori signifikansi klinis 5 memiliki tingkat keparahan minor yaitu menimbulkan efek yang ringan dan respon klinis yang dialami pasien dapat mengalami perubahan atau tidak. Contoh kasusnya adalah furosemide dan paracetamol dimana paracetamol menurunkan efek furosemide sehingga ekskresi prostaglandin ginjal dan aktivitas renin plasma menurun ${ }^{10}$.

Interaksi obat banyak terjadi secara farmakodinamik $(63,9 \%)$. Interaksi obat secara farmakodinamik adalah interaksi antar obat yang terjadi pada sistem reseptor, tempat kerja atau system fisiologi yang sama sehingga terjadi efek yang aditif, sinergis (saling memperkuat) dan (antagonis saling meniadakan). Dengan mengetahui mekanisme interaksi obat, farmasis dapat menentukan penatalaksanaan interaksi obat seperti menghindari kombinasi obat dengan memilih obat pengganti yang tidak berinteraksi, penyesuaian dosis obat, pemantauan pasien atau meneruskan pengobatan seperti sebelumnya jika kombinasi obat yang berinteraksi tersebut merupakan pengobatan bermakna secara klinis ${ }^{4}$.

\section{Kesimpulan}

Berdasarkan hasil penelitian dapat disimpulkan bahwa kejadian interaksi obat antihipertensi masih dikategorikan cukup tinggi $(66,2 \%)$ dengan 169 kasus. Tingginya potensi kejadian interaksi obat selama pengobatan dapat berpengaruh pada ketercapaian efek terapi dan meningkatkan resiko efek samping. Perlu adanya upaya pemberian pengobatan yang aman dan efektif untuk menghindari terjadinya resiko interaksi obat dan monitoring agar dapat mencegah terjadinya interaksi obat dan penanganan dini jika terjadinya interaksi obat aktual yang membahayakan secara klinis.

\section{Ucapan Terima Kasih}

Ucapan terima kasih juga penulis sampaikan kepada seluruh pihak terkait yang telah mendukung jalannya penelitian ini dan membantu dalam proses publikasi hasil penelitian ini. Penelitian ini juga mendapatkan ethical clearance dari Komisi Etik Penelitian Universitas Padjajaran Bandung.

\section{Daftar Pustaka}

1. American Heart Association. 2014. Heart Disease and Stroke Statistics. Amerika : AHA Statistical Update.

2. Barton, M., dan Meyer, M.R. 2009. Postmenopousal Hypertension Mechanism and Therapy. Hypertension. Vol 54. No.1.

3. Baxter, K., 2010. Stockley's drug Interactions, Ninth Edition, Pharmaceutical Press, China, pp. 623-650, 1125-1150.

4. Fradgley, S. J., 2003. Interaksi Obat, In Farmasi Klinis (Clinical Pharmacy) Menuju Pengobatan Rasional dan Penghargaaan Pilihan Pasien (Aslam, M., Tan, C. K., dan Prayitno, A., Eds.). Jakarta : PT Alex Media Computindo.

5. James P.A., Oparil S., Carter B.L., Cushman W.C., Dennison-Himmelfarb C., Handler J. et al. 2014 Evidence-Based Guideline for the Management of High 
blood Universitas Sumatera Utara 60 Pressure in Adults Report From The Panel Members Appointed to the Eight Joint National Committee (JNC 8). JAMA : 284427

6. Katzung, Bertram G. 2001. Farmakologi Dasar dan Klinik edisi ketiga. Salemba Jakarta : Medika.

7. Kemenkes RI. 2013. Riset Kesehatan Dasar; RISKESDAS. Jakarta : Balitbang Kemenkes RI.

8. Rama, M., Visnawathan, G., Achary, L.D., Attur, R.P., Reddy, P.N., 2012. Assesment of Drug-Drug Interaction among Renal Failure Patients of Nephrology Ward in a South Indian Tertiary Care Hospital. Indian J. Pharm. Sci. Vol.4

9. Sarasaty RF. 2011. Faktor-Faktor Yang Berhubungan Dengan Hipertensi Pada Kelompok Lanjut Usia Di Kelurahan Sawah Baru Kecamatan Ciputat, Kota Tangerang Selatan Tahun 2011. Skripsi. Jakarta : Program Studi Kesehatan Masyarakat Fakultas Kedokteran Dan IImu Kesehatan Universitas Islam Negeri Syarif Hidayatullah

10. Tatro, D.S. 2009. Drug Interaction Fact, The Authority on Drug Interaction. Amerika: Wolters Kluwer Health.

11. Vijan, S., Hayward, R.A., 2003. Treatment of Hypertension in Type 2 Diabetes Mellitus: Goals, Choice of Agents, and Setting Priorities in Diabetes Care: Blood Pressure. Annals of Internal Medicine. Vol 138 Hal 593-602

12. Yasin, N.M, Herlina T.W dan Endah K.D. 2005. Kajian Interaksi Obat pada Pasien dengan Gagal Jantung Kongestif di RSUP DR.Sardjito Yogyakarta Tahun 2005. Jurnal Farmasi Indonesia. Vol.4 Hal 15 -22. 